\title{
Fermentation of Agri-Food Waste: A Promising Route for the Production of Aroma Compounds
}

\author{
Jasmine Hadj Saadoun (D), Gaia Bertani, Alessia Levante (D), Fabio Vezzosi, Annalisa Ricci, Valentina Bernini * \\ and Camilla Lazzi (D)
}

check for updates

Citation: Hadj Saadoun, J.; Bertani, G.; Levante, A.; Vezzosi, F.; Ricci, A.; Bernini, V.; Lazzi, C. Fermentation of Agri-Food Waste: A Promising Route for the Production of Aroma Compounds. Foods 2021, 10, 707. https://doi.org/10.3390/foods 10040707

Academic Editors: Graziana Difonzo, Silvia Grassi and Maria Paciulli

Received: 26 February 2021

Accepted: 22 March 2021

Published: 26 March 2021

Publisher's Note: MDPI stays neutral with regard to jurisdictional claims in published maps and institutional affiliations.

Copyright: (c) 2021 by the authors. Licensee MDPI, Basel, Switzerland. This article is an open access article distributed under the terms and conditions of the Creative Commons Attribution (CC BY) license (https:// creativecommons.org/licenses/by/ $4.0 /)$.
Department of Food and Drug, University of Parma, Parco Area delle Scienze 49/A, 43124 Parma, Italy; jasmine.hadjsaadoun@unipr.it (J.H.S.); gaia.bertani@unipr.it (G.B.); alessia.levante@unipr.it (A.L.); fabio.vezzosi.fv@gmail.com (F.V.); annalisa.ricci@unipr.it (A.R.); camilla.lazzi@unipr.it (C.L.)

* Correspondence: valentina.bernini@unipr.it; Tel.: +39-0521906527

\begin{abstract}
Food waste and byproducts are generated along the entire food processing and storage chain. The large amount of waste deriving from the whole process represents not only a great economic loss but also an important ethical and environmental issue in terms of failure to recycle potentially reusable materials. New, clear strategies are needed to limit the amount of waste produced and, at the same time, promote its enhancement for further conversion and application to different industrial fields. This review gives an overview of the biological approaches used so far to exploit agrifood wastes and byproducts. The application of solid-state fermentation by different microorganisms (fungi, yeasts, bacteria) to produce several value-added products was analyzed, focusing on the exploitation of lactic acid bacteria as workhorses for the production of flavoring compounds.
\end{abstract}

Keywords: waste; valorization; fermentation; lactic acid bacteria; flavor

\section{Are We Sure They Are Really Waste?}

In recent decades, a new challenge concerning the reduction of food waste (FW) and food loss has been raised for the world population. Indeed, food production is increasing annually worldwide, and the Food and Agriculture Organization of the United Nations (FAO) has estimated that one-third of the products intended for human consumption (corresponding approximately to 1.3 billion tonnes/year) is wasted or lost every year [1].

This event, in developing countries, mainly originates from the first steps of the food supply chain, due to technical and management limits in the post-harvest, processing, and distribution steps. On the other hand, in medium- and high-income countries, food is lost or discarded in the final steps, by retailers and consumers, due to the high productivity and quality standards required by the market [2]. As a result, many resources are lost in terms of land, water, and nutrients, and therefore the production, processing, manufacturing, and transport steps become a waste of energy.

Considering the growth of the global population projected to 2050, to ensure an appropriate food supply, food production must increase in the next decades [3]. This will cause a rise in FW, ultimately posing a serious problem in terms of waste management and disposal.

Thus, the modern challenge is to minimize FW, optimize production processes, and move from a linear consumption and production model to a new one organized according to a circular economic strategy. In this view, FW is considered as a byproduct and resource, and several studies about waste and byproduct valorization have been conducted in recent decades [4-6].

FW is defined as any part of food that is discarded, regardless of its potential content of compounds retaining a high value [7]. Depending on its origin or production, FW can be characterized by a variable chemical composition of carbohydrates, proteins, lipids, and other components that could be used in different industries and fields [8], such 
as biorefineries, biomaterials, pharmacy, cosmetic, and aroma industries. Using food byproducts could be advantageous for the aroma industry due to market demand for natural products and their low material cost.

The aim of this review is to provide insights into biotechnological strategies performed to exploit waste and byproducts from the agri-food chain. In particular, this work is focused on the application of solid-state fermentation (SSF) to produce several valueadded products such as flavor and aroma compounds. To better delineate a specific topic, considering the metabolic potential of lactic acid bacteria (LAB), we decided to present a detailed overview of their employment in the production of natural flavors. Indeed, the involvement of these microorganisms "generally recognized as safe" (GRAS) in food processing and their role in flavor formation is well recognized, but their potential for the bioconversion of wastes and byproducts has only recently been considered. In this review, the literature is critically examined, giving an overview of the food waste management issue and presenting fermentation as an opportunity for FW bioconversion into new value.

\section{Agri-Food Waste: A Rising Problem or a Valuable Resource?}

Among the different food sectors, it is estimated that fruit and vegetables represent a large part of waste production, notably in the detail that about $45 \%$ of the total produced amount is lost in the production and consumption chains, generating a great quantity of waste material $[9,10]$. Wastes and byproducts can be classified into four source groups, according to the step of the agri-food chain in which they are generated: (i) in the fields, before harvesting, due to pest infestation and crops damaged by unfavorable weather conditions; (ii) in post-harvest and transport, where spoiled and bruised fruit and vegetables are discarded; (iii) in the different manufacturing steps process such as peeling, washing and slicing; (iv) in retail and the markets, due to natural spoilage at the end of shelf life [11].

The recovery and management of these wastes are not trivial. Seasonality, distribution across a territory, and perishability due to the high content of water and nutrients and the heterogeneity of the products may represent possible difficulties and problems for agri-food waste management [12].

A feasible and economically sustainable agri-food waste recycling program requires large volumes of raw materials concentrated in the same area, a high degree of homogeneity, and a careful analysis of downstream costs [13]. In keeping with this, industrial symbiosis could be a productive and useful strategy. The FWs generated by diverse companies could be transferred to other industries, which could transform them for other purposes in a circular economic model [14].

In recent decades, the fate of organic waste was different in different types of areas. In rural areas and farms, organic wastes were commonly used as livestock feed or were composted into humic substances used as fertilizers in fields. In urban areas, household wastes with a more complex composition were destined for incineration or landfilling, thus posing significant environmental problems with respect to air pollution and groundwater contamination [15].

The theory of waste valorization is strictly associated with sustainable technologies for recycling and reuse. The concept behind waste valorization is to enhance the value of a product by converting waste into other resources providing an added value. The resulting products could include new chemicals, materials, fuels, and energy, just like a lot of other products advantageous to local and global economies.

Furthermore, the valorization and recycling potential of agri-food wastes and byproducts can ensure sustainable food production and at the same time guarantee food security. Interestingly, some materials derived from the food industry can be reused thanks to their distinctive properties, exploitation of their physic-chemical characteristics can occur in many different industrial sectors. Lignocellulosic byproducts like soy and corn stalks or wheat straw could be used in the paper industry or as reinforcement in biodegradable polymer matrices to prepare building products with high strength [16]. 
With this in mind, currently, the most promising frontier seems to be biorefineries. Biorefineries are industries that start from biomass feedstock and, through extraction processes or chemical and biological reactions, can recover the nutrients to create valueadded products and green energy [17].

In these new industrial realities, organic materials can be treated by various techniques such as SSF, submerged fermentation (SmF), or anaerobic digestion (AD). For example, chemical compounds like bioethanol and biobutanol are obtained from starchy and lignocellulosic byproducts through fermentation by Saccharomyces cerevisiae and Clostridium acetobutyricum, respectively. In this case, saccharides must be enzymatically pre-treated to break down the polymer chains into glucose monomers which are subsequently metabolized by microorganisms [12]. Different types of biofuels can be obtained depending on their diverse starting substrates. For example, biodiesel is obtained from the transesterification of vegetable oils and animal fats, whereas methane and biohydrogen are both produced both the AD of any biodegradable substrate and by pyrolysis [17]. Another source of byproducts for bioethanol production is the sugarcane industry, whose byproducts have been proposed for $\mathrm{AD}$, microbial fermentation, and microalgae cultivation [18].

With production of over $700 \mathrm{Mt} /$ year, rice, wheat, and corn crops represent one of the main food sources worldwide. After their processing and milling, huge volumes of byproducts like stalks, straws, and husks remain [19], which could be used for biofuel production due to high cellulose and hemicellulose content.

Being biodegradable and compostable, food and beverage companies have recently begun paying great attention to biomaterials coming from renewable sources, from the perspective of environmental protection. Those are only a few examples related to new materials obtained from agri-food wastes. Bioplastic materials can be produced through the lactic acid fermentation of agro-industrial residue and household waste through engineered microorganisms. Polylactate (PLA), deriving from the polymerization of lactic acid monomers, is mainly used for the manufacturing of compostable products with a short shelf-life such as films and bags for packaging, thanks to its good transparency, biocompatibility, and processability [20]. Similarly, polyhydroxyalkanoates (PHAs) with the most representative being poly[(R)-3-hydroxybutyrate] (PHB), are used in different applications, including packaging [21].

Many compounds are also extracted and used as additives, colorants, or ingredients in food. Among them are pectin from citrus and passion fruit peels, apples, and peach pomace, which is used as a gelling agent, thickener, and food stabilizer [22]; carotenoids from tomato skins and pomace (mainly lycopene and $\beta$-carotene), carrot byproducts, mango, and orange peel. Dietary fiber can be recovered from banana peels and used in baking [8]. Orange juice fiber byproducts have been highlighted for potential use as a fat replacement in ice cream [23]; and finally, anthocyanins can be extracted from berry byproducts, grape pomace, and several exotic fruits [24]. In particular, bioactive compounds like polyphenols, flavonoids, and minerals are extracted from the losses and byproducts of fruit and vegetable industries and find use in the production of the functional food and nutraceutical sectors [25].

This policy of recycling and reuse requires not only technical knowledge but also a change of the global mindset. Wastes and by-products are often seen as useless stuff to throw away, with no thought given to their possible reuse. Furthermore, it is necessary that these wastes be seen from a perspective wider than just one company or sector. To reach the waste recycling goal, it is important that industries communicate with each other to establish a close system of valorization where an industrial symbiosis between diverse sectors can be a productive and useful strategy. 


\section{Repurposing Agri-Food Waste by Solid-State Fermentation for the Production of Aroma Compounds}

Fermentation is a well-known technique dating back to ancient civilizations for the production of food commodities such as bread, wine, and fermented milk. Microbial transformation made the products particularly appreciated for their easier digestibility, flavor, and longer shelf life. Nowadays, there is great interest in improving the health, nutritional, technological, and organoleptic qualities of fermented foods, and, thanks to the development of new starter cultures, it is possible to guide microorganisms to different substrates for the production of new compounds, including flavors [26]. The biodiversity of microorganisms can be exploited not only to produce foods with peculiar and appreciated aromatic notes, but also to convert diverse precursors into fine biochemicals such as aroma compounds and fragrances, through biocatalysis.

Fermentation is a process operated by microorganisms to break down organic compounds to obtain energy through anaerobic metabolism. This biological process is characterized by low costs, low energy consumption, and low wastewater generation, and it can be exploited to repurpose organic wastes into value-added products [27]. In SSF, fungi, yeasts, and bacteria grow on the surface of various organic substances, which act as physical support for their development without adding water [28]. Fungi and yeasts are the microorganisms of choice for this application, which is conducted at a moisture content between 40-80\% [29]. Alternatively, SmF can be applied with a moisture content of about $80-95 \%$.

Each technique has both advantages and limitations: $\mathrm{SmF}$ is routinely applied to the production of a variety of products ranging from beverages such as wine and beer to more sophisticated methods such as the cultivation of animal and plant cell cultures for biomedical applications. Despite its broad range of applications, SmF has some drawbacks regarding process scale-up, due to the requirement of large volumes of water compared to low yield [30]. SSF, on the other hand, is traditionally applied in the manufacture of various Asian fermented foods, and has recently gained attention due to its low operating cost, reduced water consumption, and the lack of requirement for sophisticated bioreactors. However, the drawbacks of this technique are the limited control of the environment within the bioreactor and the high costs for end-product recovery and downstream processing [31]. The choice of the most suitable media and microorganisms for the optimization and planning of the downstream processing steps, as well as the possibility of using low- to zerocost substrates such as food waste, represent the keys to the success of this technique [32].

As described in different studies, several added-value products can be recovered from agri-food waste substrates after fermentation, such as antibiotics, pigments, biosurfactants, hydrolytic enzymes, plastics, pesticides, and bioactive compounds [28,33-36]. Several agro-industrial wastes can be used as immobilization carriers in SSF, as reported by Orzua et al. [37], and represent an opportunity for the synthesis of industrially relevant metabolites.

Aroma compound production is a promising field for the application of SSF. Flavor compounds can be chemically synthesized, extracted directly from a natural matrix, or derived from biotechnological processes [38]. These approaches offer the possibility of obtaining additives suitable for various industrial applications, which can be labeled as "natural" and environmentally friendly as they require fewer solvents for extraction, compared to chemical synthesis methods [39]. The flavors obtained by these biotechnological processes can find applications not only as food ingredients, but also in the chemical, pharmaceutical, and cosmetic industries with the purpose of enhancing or modifying the original aroma of a product. In this way, they also acquire great importance over the acceptance of products by the consumer market [40].

Currently available biotechnological processes for aroma production (Figure 1) make use of enzymes, microbial cultures, or, less frequently, plant cell cultures [41].

The application of enzymes for the production of aroma compounds is based on their addition to the substrate during the flavor production process. Enzymes like lipase, 
protease, glucosidase, and cellulase can act on specific precursors of aromatic compounds. The result is the bioconversion of organic material into an aromatic product through a single- or multi-step catalyzed reaction [30]. One of the most promising applications is the use of lipolytic enzymes in order to produce esters [42], even if the scaling-up of this application to an industrial scale remains complicated due to the high cost. The pretreatment of grease waste with lipolytic enzymes prior to SSF was also proposed as an effective strategy to recover fatty acids from degraded grease waste [43].

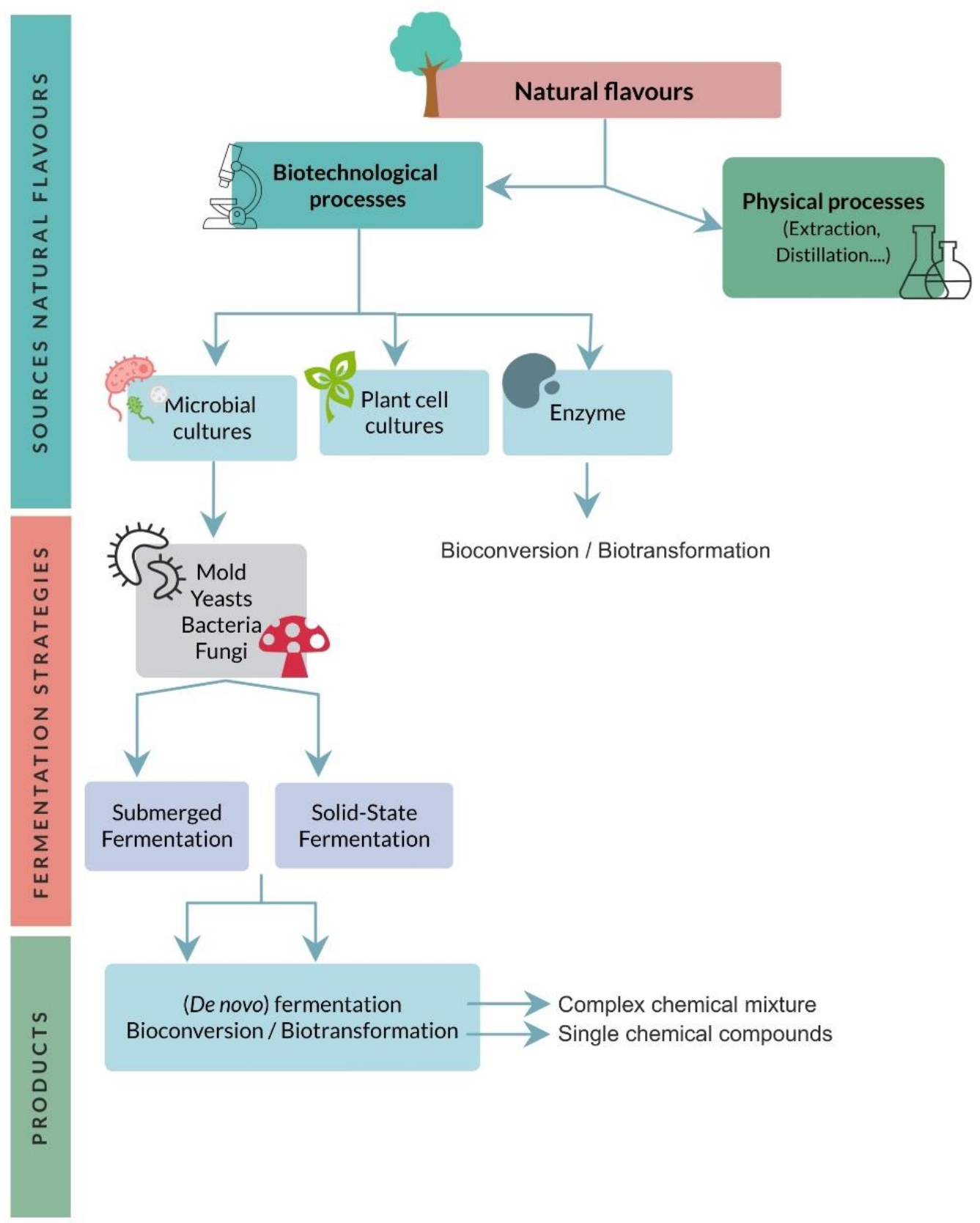

Figure 1. Processes to obtain natural flavors.

When we describe the effect of a microbial culture on a substrate, we can distinguish between bioconversion/biotransformation and fermentation. In biotransformation, the microorganism converts a precursor into a product of interest through a single- or multi-step reaction such as the conversion of ferulic acid into vanillin and the stereo- or regio-selective changes of terpenes, as reviewed by Sales et al. [38]. The biotransformation process is particularly promising for the use of engineered microorganisms. Starting from the enzyme 
which catalyzes the reaction, and knowing how the enzyme works, it is possible to insert the gene coding for that enzyme into the genomes of high-producing and better adaptable microorganisms to increase the effectiveness and efficiency of the process. The gene coding for the lipoxygenase of Pleurotus sapidus has been cloned, for example, in Escherichia coli, thus enabling it to convert valencene into the grapefruit flavor nootkatone [44].

Cereal bran and other agricultural wastes such as sugar beet pulp, rice bran oil, palm oil biomass, pineapple byproducts have been studied as sources of ferulic acid, a precursor for the conversion of bio-vanillin with natural or engineered bacteria [45,46].

Biotransformation is an easier process to apply on an industrial scale since it leads to the production of single-aroma compounds, but it is difficult to carry out using waste [47]. Furthermore, the use of genetically modified organisms is not perceived as truly "natural" by consumers [48].

In fermentation (de novo synthesis), an entire metabolic pathway is involved. The catabolism of carbohydrates, proteins, and lipids contributes to the production of the primary metabolites, which are subsequently converted into a mixture of aromatic compounds [38].

When agri-food wastes or byproducts are used as a substrate, glucose supplementation is often required to support the initial growth of microorganisms, although high concentrations might lead to catabolite repression phenomena [49]. An interesting strategy to overcome nutrient limitations occurring in SSF on agri-food waste is to mix different waste substrates, thus developing fermentation substrates that do not require nutrient supplementation. With this aim, an SSF of mixed agri-food wastes with Kluyveromyces marxianus, S. cerevisiae, or an undefined mixed culture from kefir, has been demonstrated as being a promising approach for the development of biorefineries aimed at the production of biomasses and volatile aroma compounds [50].

The production of specific compounds has been demonstrated to be inducible by adding precursors. For example, the addition of leucine and valine to growth substrates including agri-food waste, leads to the formation of isoamyl acetate with a strong banana aroma $[51,52]$, due to the Ehrlich pathway that leads to the catabolism of the amino acid and the production of esters as final products [53]. Other derivatives of the Ehrlich pathways are the rose-scented volatile compounds 2-phenylethanol and 2-phenethyl acetate, which were synthetized through the SSF of sugarcane bagasse upon the addition of L-phenylalanine as a precursor, from the yeasts K. marxianus and Pichia kudriavzevii [54,55].

Several studies have been conducted on the use of microbial cultures (especially molds and yeasts) growing on agri-food wastes and byproducts, to produce aromatic compounds, and a list of the main results is reported in Table 1.

The optimization of SSF approaches relies consistently on the isolation of novel strain/substrate combinations, and strain selection a key point of the process due to the strain-specific capabilities of volatile compound production [66]. It is also known that the microbial growth phase can affect the production of volatile compounds [70,71], and the optimization of SSF processes suggests that the metabolic state of microbial cells can influence their synthesis [72]. Yet, the limited knowledge of bacterial physiology during SSF and the regulation of the pathways involved in aroma formation represents a limit to the optimization of strain selection and operating procedures [73].

The fermentation processes are followed by bioseparation processes such as extraction, purification, and the recovery of the compound of interest. Due to compound volatility and low solubility, recovery is the most difficult step, particularly for flavor components [74]. Deep knowledge of the properties of the target compounds and the matrix in which they are dispersed is necessary, to choose the most appropriate extraction method, to increase selectivity and efficiency, and thus to obtain the maximum recovery of the product from SSF. 
Table 1. Aroma production by SSF of agri-food wastes/byproducts, using molds and yeasts.

\begin{tabular}{|c|c|c|c|c|}
\hline & Agri-Food Waste & Pretreatment(s) & Aroma & Reference \\
\hline \multicolumn{5}{|l|}{ Mold } \\
\hline \multirow{4}{*}{ Ceratocystis fimbriata } & $\begin{array}{l}\text { Citrus pulp }+25 \% \text { sugarcane } \\
\text { molasses }(+50 \% \text { soya bran })\end{array}$ & Drying, milling, sieving & Fruity aroma & {$[56]$} \\
\hline & Coffee husks (+glucose) & $\begin{array}{l}\text { Milling, } \\
\text { steam treatment }\end{array}$ & $\begin{array}{c}\text { Pineapple aroma } \\
\text { (acetaldehyde, ethanol, } \\
\text { isopropanol, ethyl acetate) }\end{array}$ & [49] \\
\hline & Coffee husks & $\begin{array}{l}\text { Drying, milling, } \\
\text { sieving, sterilization }\end{array}$ & Fruity flavor & [57] \\
\hline & $\begin{array}{c}\text { Cassava bagasse, apple } \\
\text { pomace, amaranth, soybean }\end{array}$ & $\begin{array}{l}\text { Drying, milling, } \\
\text { sieving, sterilization }\end{array}$ & $\begin{array}{c}\text { Fruity aroma } \\
\text { (+ amaranth and } \\
+ \text { banana aroma })\end{array}$ & {$[52]$} \\
\hline \multirow{2}{*}{ Rhizopus oryzae } & $\begin{array}{c}\text { Wheat bran, cassava bagasse, } \\
\text { sugarcane bagasse }\end{array}$ & $\begin{array}{l}\text { Milling, sieving, } \\
\text { sterilization. For sugar } \\
\text { cane bagasse: } \\
\text { preliminary washing }\end{array}$ & $\begin{array}{c}\text { Fruity aroma } \\
\text { (strong banana aroma) }\end{array}$ & [58] \\
\hline & $\begin{array}{l}\text { Cassava bagasse, } \\
\text { apple pomace, soybean, } \\
\text { amaranth, soybean oil }\end{array}$ & $\begin{array}{c}\text { Grinding, } \\
\text { drying, sterilization }\end{array}$ & $\begin{array}{l}\text { Acetaldehyde, Ethanol, } \\
\text { 1-Propanol, Ethyl acetate, } \\
\text { Ethyl propionate, } \\
\text { 3-Methyl butanol }\end{array}$ & [59] \\
\hline Trichoderma viride & Sugarcane bagasse & Drying, milling & $\begin{array}{l}\text { Coconut aroma, } \\
\text { 6-pentyl- } \alpha \text {-pyrone } \\
\text { Coconut aroma, } \\
\text { 6-pentyl- } \alpha \text {-pyrone, } \\
\text { from } \delta \text {-Octalactone } \\
\text { to Dodecalactone }\end{array}$ & {$[60]$} \\
\hline Trichoderma harzianum & Sugarcane bagasse & Drying, milling & 6-Pentyl- $\alpha$-pyrone & {$[62,63]$} \\
\hline \multirow{3}{*}{ Kluyveromyces marxianus } & $\begin{array}{l}\text { Apple pomace, cassava } \\
\text { bagasse, sugar cane bagasse, } \\
\text { sunflower seeds, giant palm }\end{array}$ & $\begin{array}{l}\text { Drying, milling, } \\
\text { sieving, sterilization }\end{array}$ & Ethanol, ethyl acetate & {$[64]$} \\
\hline & \multirow{2}{*}{$\begin{aligned} & \text { Sugarcane bagasse } \\
+ & \text { sugar beet molasses }\end{aligned}$} & $\begin{array}{l}\text { Drying, milling, } \\
\text { pH adjustment }\end{array}$ & $\begin{array}{c}\text { Fruity aroma } \\
\text { (43\% alcohol, 35\% esters) }\end{array}$ & [54] \\
\hline & & $\begin{array}{l}\text { Drying, milling, } \\
\text { pH adjustment }\end{array}$ & Fruity aroma & {$[55]$} \\
\hline $\begin{array}{c}\text { Aspergilius niger, } \\
\text { Penicilium cinnabarium }\end{array}$ & $\begin{array}{l}\text { Rice brain oil residue } \\
\quad(+ \text { ferulic acid })\end{array}$ & $\begin{array}{c}\text { Water-ethanl extraction, } \\
\mathrm{pH} \text { adjustment, } \\
\text { filter sterilization }\end{array}$ & Vanillin & {$[65]$} \\
\hline $\begin{array}{c}\text { Hanseniaspora velbyensis } \\
\text { and uvarum, } \\
\text { Saccharomyces cerevisiae }\end{array}$ & Apple peels & Drying, homogenization & 132 volatile compounds & {$[66]$} \\
\hline \multicolumn{5}{|l|}{ Yeasts } \\
\hline Pichia kudriavzevii & $\begin{array}{l}\text { Sugarcane bagasse } \\
+1 \text {-phenylalanine }\end{array}$ & $\begin{array}{l}\text { Drying, milling, } \\
\text { pH adjustment }\end{array}$ & Rose aroma & [67] \\
\hline Saccharomyces cerevisiae & Citrus peels & Slicing, grinding & $\begin{array}{c}\text { Isoamylacetate, ethyl } \\
\text { dodecanoate, ethyl } \\
\text { decanoate, ethyl hexanoate }\end{array}$ & [68] \\
\hline $\begin{array}{l}\text { Yarrowia lipolytica } \\
\text { (engineered) }\end{array}$ & Fatty feedstock & N.d. & $\begin{array}{l}\text { Coconut like flavor } \\
(\gamma \text {-dodecalactone, } \\
\delta \text {-decalactone })\end{array}$ & [69] \\
\hline $\begin{array}{l}\text { Kefir (symbiotic yeasts } \\
\text { and bacteria) }\end{array}$ & $\begin{array}{l}\text { Food industrial wastes (cheese } \\
\text { whey, molasses, brewer's spent } \\
\text { grains, malt spent rootlets, } \\
\text { orange and potato pulp) }\end{array}$ & Blending & $\epsilon$-pinene & [50] \\
\hline
\end{tabular}


There are many techniques available for the isolation of flavor compounds, and although there is no correct technique in general, the challenge is to find the one most suitable capable of extracting the desired flavors in the best way, avoiding losses of volatile compounds during the process due to the aeration of the SSF bioreactors [75]. A combination of different extraction and separation techniques (hybrid processes) often proves beneficial for large-scale applications [76]. Next to the traditional extraction methods, the development of non-conventional techniques aims to improve the efficiency of extractive processes of bioactive compounds. These techniques can reduce the time and temperature of extraction while maintaining high selectivity and high yield using less dangerous solvents, and that is why they are considered "green techniques" [77]. Considering all these aspects, it would be desirable that an increasing number of studies report preliminary cost analyses, to provide orientation for future development of this industrial process [50]. Figure 2 summarizes these techniques, highlighting the pros and cons of each.

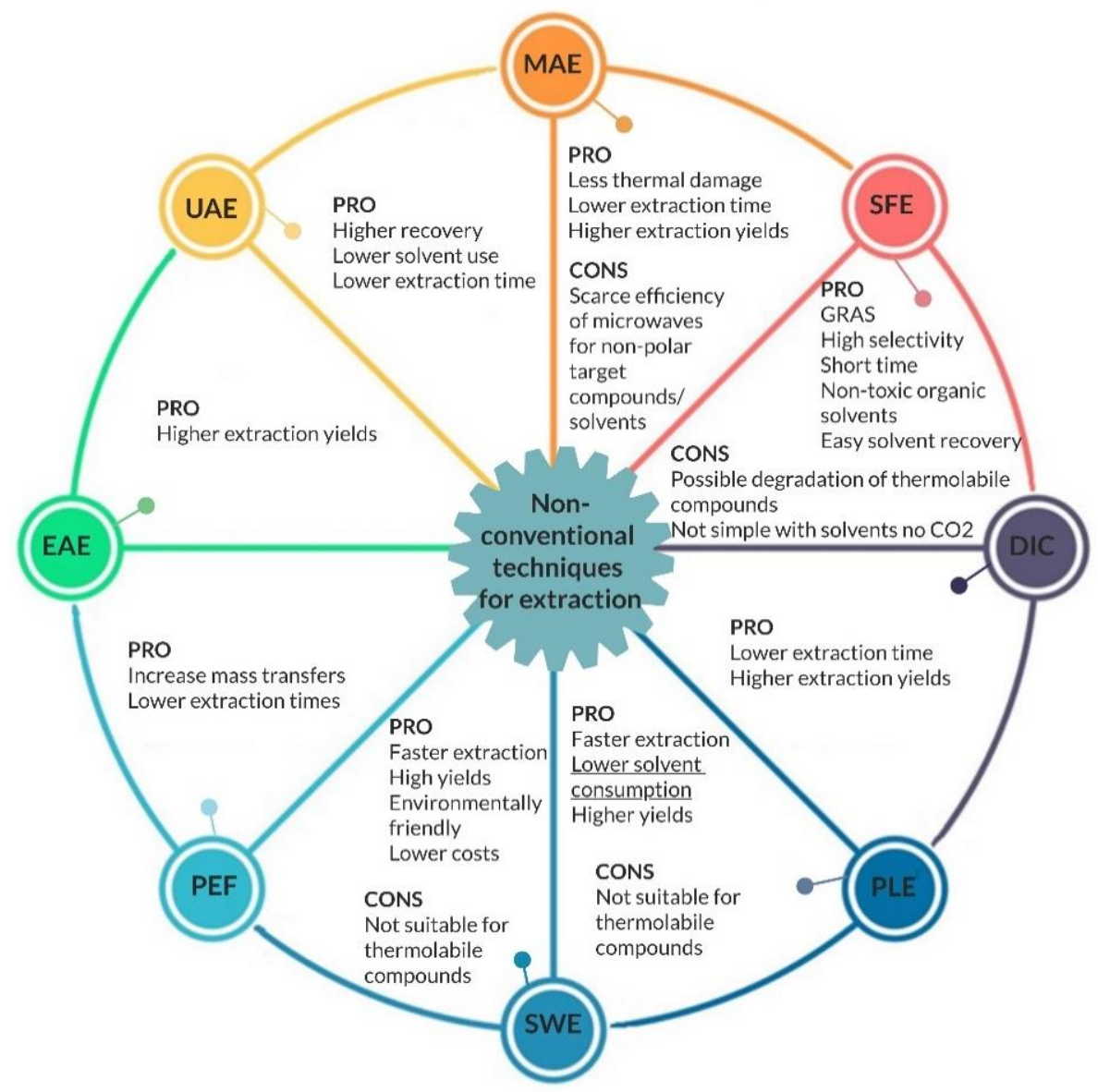

Figure 2. Operating principles of nonconventional techniques with their main advantages (PRO) and disadvantages (CONS) compared to traditional techniques. UAE, ultrasound-assisted extraction; MAE, microwave-assisted extraction; SFE, supercritical fluid extraction; DIC, instant controlled pressure drop-assisted extraction; PLE, pressurized liquid extraction; SWE, subcritical water extraction; PEF, pulsed electric field; EAE, enzyme-assisted extraction.

\section{Lactic Acid Bacteria: Biological Resources for Volatile Compound Production}

LAB are widely used in the food industry as starters, to drive fermentation processes, and as probiotic sources. LAB are easy to employ because they are recognized as GRAS, have a simple metabolism, can grow on many different carbon sources, and have a good tolerance to environmental stresses such as $\mathrm{pH}$ and temperature [78]. In recent years, the development of genome sequencing techniques and genetic tools has widened the range of applications, helping to control the bioproduction of value-added products and 
standardize the process. All of these characteristics make it possible to exploit LAB in biorefineries for the production of various types of value-added products, such as lactic acid, plastic polymers, ethanol, exopolysaccharides (with thickener and prebiotics function), antimicrobial molecules, food aromas, and sweeteners (sorbitol, mannitol, l-alanine) [78].

Recently, various studies have been dedicated to the lactic acid fermentation of different substrates $[79,80]$ using Lacticaseibacillus rhamnosus for the evaluation of the aromatic component which undergoes modifications during the process. Fermentation can be used to increase aromatic notes [81] or to reduce off-flavor components in the products [82]. Changes to the aromatic profile derive from the metabolism of bacteria which, depending on the various nutritional compounds available, produce different metabolites. Microorganisms metabolize carbon sources for growth and energy production during fermentation. The resulting metabolites can be both aromatic compounds and aroma precursors [53]. These compounds have specific sensory attributes, for example, esters are characterized for the most part by sweet smell [30], while aldehydes usually bring floral or fruity notes [83].

Important and complex aromatic molecules are known to be generated by LAB during the fermentation of dairy foods. These compounds are synthetized as a result of the primary metabolism of carbon sources (lactic acid and mixed acid fermentation), or by proteolisys and other secondary metabolisms that occur during the cheese ripening step. The buttery flavor seems to be the most interesting compound produced by LAB in qualitative and quantitative terms and is widely used in bakery. The molecule that best expresses this flavor is diacetyl, followed by acetoin, butanediol, and acetaldehyde. The above, and other metabolites such as ethanol and acetate, derives from pyruvate, which gives a typical flavor to fermented foods. Only some species of LAB, with the ability to metabolize citrate, can produce diacetyl [84]. The microbial synthesis of diacetyl, in Lactococcus lactis, is stimulated in acidic conditions and seems to be produced to control intracellular $\mathrm{pH}$ [85]. Papagianni [86] has examined several approaches that have been adopted to improve the production of diacetyl. In aerobic conditions, the pyruvate pathway is shifted to the synthesis of $\alpha$-acetolactate, the reaction is catalyzed by two enzymes: $\alpha$-acetolactate synthase (ALS) or acetohydroxy acid synthase (ILVBN). Acetolactate can be either converted into diacetyl by an oxidative reaction or into acetoin by decarboxylation with the enzyme $\alpha$-acetolactate decarboxylase (ALDB). Genetic engineering has attempted to inactivate the gene that expresses ALDB and to overexpress the ALS and ILVBN genes, with little success. In contrast, the overproduction of NADH oxidase (NOX) in Lactococcus lactis, in addition to the inactivation of ALDB gene, has been shown to be successful in driving the metabolism of pyruvate in the production of diacetyl, rather than lactate [87]. In this way, L. lactis has increases diacetyl production at the same time as it reduces lactate production [88].

In this context, many efforts have been aimed at the construction through metabolic engineering of recombinant strains to enhance flavor production, as well as to the screening of LAB collections, in particular Lactobacillus spp., to determine their metabolic potential for the synthesis of flavor compounds and create a better definition of acetoin production through transcriptional activation [89-91].

In recent studies, lactic acid fermentation was selected as a process for enhancing the flavor profile of fruit juice. Although most volatile compounds occur naturally in plants, they can be synthesized by microorganisms as secondary metabolites. Chen et al. [92] observed a positive modification on the aromatic profile of apple juice fermented with different LAB strains (belonging to the genus Lactobacillus), particularly an increase of alcohols like 2-ethylhexanol and ethyl acetate with floral and fruity notes. The same results were recorded in other fruit juices such as pomegranate [93], where the fermented juice, with L. plantarum, had a more intense fruity note that can result from an increase in alcohols, ketones, and terpenes; or in elderberry juice [70], where LAB increased the volatile compounds typical of elderberr, like $\beta$-damascenone and various alcohols such as hexanol, 3-hexen-1-ol (Z), 2-hexen-1-ol (E), ethanol, 2-phenylmethanol, 2-phenylethanol, isoamyl alcohol, hexanol, 3-hexen-1-ol (Z), and 2-hexen-1-ol (E). During the fermentation of barley malt wort beverages [94] with different LAB strains, a higher aroma yield and 
fruity flavor was recorded, due to the increase of some compounds like $\beta$-damascenone, furaneol, 2-phenylethanol, and ethyl 2-methylbutanoate.

The activation of the metabolic pathways that lead to the formation of certain aromatic compounds is, however, closely related to the strain and the substrates used for fermentation. Thanks to the unique portfolio of enzymes that LAB possess, they activate different metabolisms, such as the catabolism of aldehydes, the synthesis and hydrolysis of esters, the degradation of phenolic acids, lipolysis, proteolysis, and peptidolysis [95].

Despite the number of studies on lactic acid fermentation showing an improvement in the sensory qualities in fermented products, the use of LAB for the production of aromas from waste and byproducts has been rarely studied $[79,80]$. LAB can grow on many different substrates, among which are ligno-cellulosic byproducts, agri-food, and municipal solid wastes [96,97].

Almost all LAB are not able to directly ferment complex polysaccharides like starch or hemicellulose, and therefore hydrolysis pretreatments (with related costs) are necessary, together with the addition of amino acids, nucleotides, and vitamins [78]. For the direct exploitation of these economic feedstocks, some strategies have been implemented, including the co-cultivation of LAB with native cellulolytic microorganisms and the modification of the gene pool by inserting hydrolytic genes for saccharification [98]. Escamilla Hurtado et al. [99] reported that the production of diacetyl with Pediococcus pentosaceus and Lactobacillus acidophilus increases on starchy substrates according to different parameters.

Moreover, the use of Kefir (granules containing lactic acid and acetic bacteria and fermenting yeasts) in SSF on food industry wastes showed significant production of $\varepsilon$-pinene (Table 1), with an estimated yield in biorefineries of $4 \mathrm{Kg}$ per ton of treated substrate [50].

\section{Conclusions}

Recent years have witnessed a rapid evolution of different methods of natural flavor and fragrance chemical production through biotechnological routes. The use of microbial cultures offers several advantages over traditional methodologies, such as the possibility to label flavors as "natural," thus making them more attractive for consumption, with market acceptability. Agri-food waste exploitation can be of great help, often offering excellent substrates for microbial growth and enhancing waste recovery and valorization at the same time. High operating costs are among the main issues to solve for the implementation of these production systems. The employment of LAB offers the possibility of adding value to agri-food waste by producing natural flavors. Their use offers advantages compared to other microorganisms, such as GRAS status and good adaptability to different carbon sources and environmental stress, with the disadvantages being that they often need pretreatment to make sugar available and nutrient supplementations. FWs used as a substrate can overpass the last issue. Moreover, the techniques of genetic modification in $\mathrm{LAB}$ are being rapidly developed thanks to the completion of genome sequencing and the wide availability of handling techniques. In light of the wide applicability of LAB fermentations, few studies have addressed the efficiency of this approach for the synthesis of aromatic compounds using agri-food waste as a substrate.

Undoubtedly, a careful assessment of production and downstream costs will be required to guarantee the economy of the design process. SSF technology has yet not been fully implemented at the industrial scale because of the lack of easily scalable reactors able to successfully overcome the problems with heterogeneity and sterility. Consequently, further targeted studies are needed to assess the most effective methods for the extraction and separation of flavor compounds at the industrial scale.

Author Contributions: Conceptualization, C.L.; investigation, J.H.S., F.V.; writing-original draft preparation, J.H.S., G.B., A.L., F.V., A.R., V.B., C.L.; writing-review and editing J.H.S., G.B., A.L., A.R., V.B., C.L. All authors have read and agreed to the published version of the manuscript.

Funding: This research received no external funding.

Institutional Review Board Statement: Not applicable. 
Informed Consent Statement: Not applicable.

Data Availability Statement: Not applicable.

Conflicts of Interest: The authors declare no conflict of interest.

\section{References}

1. FAO. Food Wastage Footprint. Impact on Natural Resources; Summary Report; FAO: Rome, Italy, 2013 ; ISBN 978925107752.

2. $\quad$ FAO. Global Initiative on Food Loss and Waste Reduction; FAO: Rome, Italy, 2015.

3. Take Action for the Sustainable Development Goals-United Nations Sustainable Development. Available online: https: / / www.un.org/sustainabledevelopment/sustainable-development-goals / (accessed on 28 January 2021).

4. Barba, F.J.; Putnik, P.; Bursać Kovačević, D.; Poojary, M.M.; Roohinejad, S.; Lorenzo, J.M.; Koubaa, M. Impact of conventional and non-conventional processing on prickly pear (Opuntia spp.) and their derived products: From preservation of beverages to valorization of by-products. Trends Food Sci. Technol. 2017, 67, 260-270. [CrossRef]

5. Clementz, A.; Torresi, P.A.; Molli, J.S.; Cardell, D.; Mammarella, E.; Yori, J.C. Novel method for valorization of by-products from carrot discards. LWT 2019, 100, 374-380. [CrossRef]

6. Gullón, P.; Gullón, B.; Astray, G.; Carpena, M.; Fraga-Corral, M.; Prieto, M.A.; Simal-Gandara, J. Valorization of by-products from olive oil industry and added-value applications for innovative functional foods. Food Res. Int. 2020, 137, 109683. [CrossRef] [PubMed]

7. Hartikainen, H.; Mogensen, L.; Svanes, E.; Franke, U. Food waste quantification in primary production-The Nordic countries as a case study. Waste Manag. 2018, 71, 502-511. [CrossRef]

8. Galanakis, C. Food Waste Valorization Opportunities for Different Food Industries; Elsevier Inc.: Amsterdam, The Netherlands, 2020; ISBN 9780128164495.

9. Fidelis, M.; de Moura, C.; Kabbas Junior, T.; Pap, N.; Mattila, P.; Mäkinen, S.; Putnik, P.; Bursać Kovačević, D.; Tian, Y.; Yang, B.; et al. Fruit Seeds as Sources of Bioactive Compounds: Sustainable Production of High Value-Added Ingredients from By-Products within Circular Economy. Molecules 2019, 24, 3854. [CrossRef] [PubMed]

10. Sagar, N.A.; Pareek, S.; Sharma, S.; Yahia, E.M.; Lobo, M.G. Fruit and Vegetable Waste: Bioactive Compounds, Their Extraction, and Possible Utilization. Compr. Rev. Food Sci. Food Saf. 2018, 17, 512-531. [CrossRef] [PubMed]

11. Ravindran, R.; Jaiswal, A.K. Exploitation of Food Industry Waste for High-Value Products. Trends Biotechnol. 2016, 34, 58-69. [CrossRef]

12. Girotto, F.; Alibardi, L.; Cossu, R. Food waste generation and industrial uses: A review. Waste Manag. 2015, 45, 32-41. [CrossRef]

13. Pfaltzgraff, L.A.; De Bruyn, M.; Cooper, E.C.; Budarin, V.; Clark, J.H. Food waste biomass: A resource for high-value chemicals. Green Chem. 2013, 15, 307-314. [CrossRef]

14. Mirabella, N.; Castellani, V.; Sala, S. Current options for the valorization of food manufacturing waste: A review. J. Clean. Prod. 2014, 65, 28-41. [CrossRef]

15. Sánchez, A.; Artola, A.; Font, X.; Gea, T.; Barrena, R.; Gabriel, D.; Sánchez-Monedero, M.Á.; Roig, A.; Cayuela, M.L.; Mondini, C. Greenhouse gas emissions from organic waste composting. Environ. Chem. Lett. 2015, 13, 223-238. [CrossRef]

16. Bhuyan, N.; Narzari, R.; Gogoi, L.; Bordoloi, N.; Hiloidhari, M.; Palsaniya, D.R.; Deb, U.; Gogoi, N.; Kataki, R. Valorization of agricultural wastes for multidimensional use. In Current Developments in Biotechnology and Bioengineering; Elsevier: Amsterdam, The Netherlands, 2020; pp. 41-78.

17. Carmona-Cabello, M.; Garcia, I.L.; Leiva-Candia, D.; Dorado, M.P. Valorization of food waste based on its composition through the concept of biorefinery. Curr. Opin. Green Sustain. Chem. 2018, 14, 67-79. [CrossRef]

18. Sydney, E.B.; de Carvalho, J.C.; Letti, L.A.J.; Magalhães, A.I.; Karp, S.G.; Martinez-Burgos, W.J.; de Souza Candeo, E.; Rodrigues, C.; de SouzaVandenberghe, L.P.; Neto, C.J.D.; et al. Current developments and challenges of green technologies for the valorization of liquid, solid, and gaseous wastes from sugarcane ethanol production. J. Hazard. Mater. 2021, 404, 124059. [CrossRef]

19. Bledzki, A.K.; Mamun, A.A.; Volk, J. Physical, chemical and surface properties of wheat husk, rye husk and soft wood and their polypropylene composites. Compos. Part A Appl. Sci. Manuf. 2010, 41, 480-488. [CrossRef]

20. Armentano, I.; Bitinis, N.; Fortunati, E.; Mattioli, S.; Rescignano, N.; Verdejo, R.; Lopez-Manchado, M.A.; Kenny, J.M. Multifunctional nanostructured PLA materials for packaging and tissue engineering. Prog. Polym. Sci. 2013, 38, 1720-1747. [CrossRef]

21. Masood, F.; Yasin, T.; Hameed, A. Polyhydroxyalkanoates-What are the uses? Current challenges and perspectives. Crit. Rev. Biotechnol. 2015, 35, 514-521. [CrossRef] [PubMed]

22. Naqash, F.; Masoodi, F.A.; Rather, S.A.; Wani, S.M.; Gani, A. Emerging concepts in the nutraceutical and functional properties of pectin-A Review. Carbohydr. Polym. 2017, 168, 227-239. [CrossRef] [PubMed]

23. De Moraes Crizel, T.; Jablonski, A.; de Oliveira Rios, A.; Rech, R.; Flôres, S.H. Dietary fiber from orange byproducts as a potential fat replacer. LWT Food Sci. Technol. 2013, 53, 9-14. [CrossRef]

24. Klavins, L.; Kviesis, J.; Nakurte, I.; Klavins, M. Berry press residues as a valuable source of polyphenolics: Extraction optimisation and analysis. LWT 2018, 93, 583-591. [CrossRef]

25. Ben-Othman, S.; Jõudu, I.; Bhat, R. Bioactives from Agri-Food Wastes: Present Insights and Future Challenges. Molecules 2020, 25, 510. [CrossRef] 
26. Pereira, G.V.D.M.; Neto, D.P.D.C.; Junqueira, A.C.D.O.; Karp, S.G.; Letti, L.A.J.; Júnior, A.I.M.; Soccol, C.R. A Review of Selection Criteria for Starter Culture Development in the Food Fermentation Industry. Food Rev. Int. 2020, 36, 135-167. [CrossRef]

27. Tlais, A.Z.A.; Fiorino, G.M.; Polo, A.; Filannino, P.; Di Cagno, R. High-Value Compounds in Fruit, Vegetable and Cereal Byproducts: An Overview of Potential Sustainable Reuse and Exploitation. Molecules 2020, 25, 2987. [CrossRef] [PubMed]

28. Yazid, N.A.; Barrena, R.; Komilis, D.; Sánchez, A. Solid-state fermentation as a novel paradigm for organic waste valorization: A review. Sustainability 2017, 9, 1-28.

29. Ali, H.; Zulkali, M. Utilization of Agro-Residual Ligno-Cellulosic Substances by Using Solid State Fermentation: A Review. Hrvat. Časopis Prehrambenu Tehnol. Biotehnol. Nutr. 2011, 6, 5-12.

30. Ben Akacha, N.; Gargouri, M. Microbial and enzymatic technologies used for the production of natural aroma compounds: Synthesis, recovery modeling, and bioprocesses. Food Bioprod. Process. 2015, 94, 675-706. [CrossRef]

31. Arora, S.; Rani, R.; Ghosh, S. Bioreactors in solid state fermentation technology: Design, applications and engineering aspects. J. Biotechnol. 2018, 269, 16-34. [CrossRef]

32. Singhania, R.R.; Kumar Patel, A.; Soccol, C.R.; Pandey, A. Recent advances in solid-state fermentation. Biochem. Eng. J. 2009, 44, 13-18. [CrossRef]

33. Cerda, A.; Artola, A.; Barrena, R.; Font, X.; Gea, T.; Sánchez, A. Innovative Production of Bioproducts from Organic Waste Through Solid-State Fermentation. Front. Sustain. Food Syst. 2019, 3, 1-6. [CrossRef]

34. Couto, S.R.; Sanromán, M.Á. Application of solid-state fermentation to food industry-A review. J. Food Eng. 2006, 76, 291-302. [CrossRef]

35. Lizardi-Jiménez, M.A.; Hernández-Martínez, R. Solid state fermentation (SSF): Diversity of applications to valorize waste and biomass. 3 Biotech. 2017, 7, 44. [CrossRef] [PubMed]

36. Martins, S.; Mussatto, S.I.; Martínez-avila, G.; Montañez-saenz, J.; Aguilar, C.N.; Teixeira, J.A. Bioactive phenolic compounds: Production and extraction by solid-state fermentation. A review. Biotechnol. Adv. 2011, 29, 365-373. [CrossRef]

37. Orzua, M.C.; Mussatto, S.I.; Contreras-Esquivel, J.C.; Rodriguez, R.; De La Garza, H.; Teixeira, J.A.; Aguilar, C.N. Exploitation of agro industrial wastes as immobilization carrier for solid-state fermentation. Ind. Crops Prod. 2009, 30, 24-27. [CrossRef]

38. Sales, A.; Paulino, B.N.; Pastore, G.M.; Bicas, J.L. Biogeneration of aroma compounds. Curr. Opin. Food Sci. 2018, 19, 77-84. [CrossRef]

39. de Oliveira Felipe, L.; de Oliveira, A.M.; Bicas, J.L. Bioaromas-Perspectives for sustainable development. Trends Food Sci. Technol. 2017, 62, 141-153. [CrossRef]

40. Pessôa, M.G.; Vespermann, K.A.C.; Paulino, B.N.; Barcelos, M.C.S.; Pastore, G.M.; Molina, G. Newly isolated microorganisms with potential application in biotechnology. Biotechnol. Adv. 2019, 37, 319-339. [CrossRef]

41. Longo, M.A.; Sanromán, M.A. Production of food aroma compounds: Microbial and enzymatic methodologies. Food Technol. Biotechnol. 2006, 44, 335-353.

42. Kumar, A.; Gudiukaite, R.; Gricajeva, A.; Sadauskas, M.; Malunavicius, V.; Kamyab, H.; Sharma, S.; Sharma, T.; Pant, D. Microbial lipolytic enzymes-Promising energy-efficient biocatalysts in bioremediation. Energy 2020, 192, 116674. [CrossRef]

43. Kumari, A.; Ahmad, R.; Negi, S.; Khare, S.K. Biodegradation of waste grease by Penicillium chrysogenum for production of fatty acid. Bioresour. Technol. 2017, 226, 31-38. [CrossRef] [PubMed]

44. Zelena, K.; Krings, U.; Berger, R.G. Functional expression of a valencene dioxygenase from Pleurotus sapidus in E. coli. Bioresour. Technol. 2012, 108, 231-239. [CrossRef] [PubMed]

45. Zamzuri, N.A.; Abd-Aziz, S. Biovanillin from agro wastes as an alternative food flavour. J. Sci. Food Agric. 2013, 93, 429-438. [CrossRef] [PubMed]

46. Tang, P.L.; Hassan, O. Bioconversion of ferulic acid attained from pineapple peels and pineapple crown leaves into vanillic acid and vanillin by Aspergillus niger I-1472. BMC Chem. 2020, 14, 1-11. [CrossRef]

47. Carroll, A.L.; Desai, S.H.; Atsumi, S. Microbial production of scent and flavor compounds. Curr. Opin. Biotechnol. 2016, 37, 8-15. [CrossRef]

48. Boccia, F.; Covino, D.; Sarnacchiaro, P. Genetically modified food versus knowledge and fear: A Noumenic approach for consumer behaviour. Food Res. Int. 2018, 111, 682-688. [CrossRef]

49. Soares, M.; Christen, P.; Pandey, A.; Soccol, C.R. Fruity flavour production by Ceratocystis fimbriata grown on coffee husk in solid-state fermentation. Process. Biochem. 2000, 35, 857-861. [CrossRef]

50. Aggelopoulos, T.; Katsieris, K.; Bekatorou, A.; Pandey, A.; Banat, I.M.; Koutinas, A.A. Solid state fermentation of food waste mixtures for single cell protein, aroma volatiles and fat production. Food Chem. 2014, 145, 710-716. [CrossRef] [PubMed]

51. Quilter, M.G.; Hurley, J.C.; Lynch, F.J.; Murphy, M.G. The Production of Isoamyl Acetate from Amyl Alcohol by Saccharomyces cerevisiae. J. Inst. Brew. 2003, 109, 34-40. [CrossRef]

52. Bramorski, A.; Soccol, C.R.; Christen, P.; Revah, S. Fruity aroma production by Ceratocystis fimbriata in solid cultures from agro-industrial wastes. Rev. Microbiol. 1998, 29, 208-212. [CrossRef]

53. Shetty, K.; Sarkar, D. Functional Foods and Biotechnology: Biotransformation and Analysis of Functional Foods and Ingredients; CRC Press: Boca Raton, FL, USA, 2020.

54. Martínez, O.; Sánchez, A.; Font, X.; Barrena, R. Valorization of sugarcane bagasse and sugar beet molasses using Kluyveromyces marxianus for producing value-added aroma compounds via solid-state fermentation. J. Clean. Prod. 2017, 158, 8-17. [CrossRef] 
55. Martínez, O.; Sánchez, A.; Font, X.; Barrena, R. Enhancing the bioproduction of value-added aroma compounds via solid-state fermentation of sugarcane bagasse and sugar beet molasses: Operational strategies and scaling-up of the process. Bioresour. Technol. 2018, 263, 136-144. [CrossRef] [PubMed]

56. Rossi, S.C.; Vandenberghe, L.P.S.; Pereira, B.M.P.; Gago, F.D.; Rizzolo, J.A.; Pandey, A.; Soccol, C.R.; Medeiros, A.B.P. Improving fruity aroma production by fungi in SSF using citric pulp. Food Res. Int. 2009, 42, 484-486. [CrossRef]

57. Medeiros, A.B.P.; Pandey, A.; Vandenberghe, L.P.S.; Pastore, G.M.; Soccol, C.R. Production and recovery of aroma compounds produced by solid-state fermentation using different adsorbents. Food Technol. Biotechnol. 2006, 44, 47-51.

58. Christen, P.; Meza, J.C.; Revah, S. Fruity aroma production in solid state fermentation by Ceratocystis fimbriata: Influence of the substrate type and the presence of precursors. Mycol. Res. 1997, 101, 911-919. [CrossRef]

59. Christen, P.; Bramorski, A.; Revah, S.; Soccol, C.R. Characterization of volatile compounds produced by Rhizopus strains grown on agro-industrial solid wastes. Bioresour. Technol. 2000, 71, 211-215. [CrossRef]

60. De Aráujo, Á.A.; Pastore, G.M.; Berger, R.G. Production of Coconut Aroma by Fungi Cultivation in Solid-State Fermentation. In Applied Biochemistry and Biotechnology; Finkelstein, M., McMillan, J., Davison, B.H., Eds.; Humana Press: Totowa, NJ, USA, 2002; pp. 747-751. ISBN 9781461266211.

61. Fadel, H.H.M.; Mahmoud, M.G.; Asker, M.M.S.; Lotfy, S.N. Characterization and evaluation of coconut aroma produced by Trichoderma viride EMCC-107 in solid state fermentation on sugarcane bagasse. Electron. J. Biotechnol. 2015, 18, 5-9. [CrossRef]

62. Da Penha, M.P.; da Rocha Leão, M.H.M.; Leite, S.G.F. Sugarcane bagasse as support for the production of coconut aroma by solid state fermentation (SSF). BioResources 2012, 7, 2366-2375. [CrossRef]

63. Ladeira, N.C.; Peixoto, V.J.; Penha, M.P.; de Paula Barros, E.B.; Leite, S.G.F. Optimization of 6-pentyl- $\alpha$-pyrone production by solid state fermentation using sugarcane bagasse as residue. BioResources 2010, 5, 2297-2306.

64. Medeiros, A.B.; Pandey, A.; Freitas, R.J.; Christen, P.; Soccol, C.R. Optimization of the production of aroma compounds by Kluyveromyces marxianus in solid-state fermentation using factorial design and response surface methodology. Biochem. Eng. J. 2000, 6, 33-39. [CrossRef]

65. Zheng, L.; Zheng, P.; Sun, Z.; Bai, Y.; Wang, J.; Guo, X. Production of vanillin from waste residue of rice bran oil by Aspergillus niger and Pycnoporus cinnabarinus. Bioresour. Technol. 2007, 98, 1115-1119. [CrossRef]

66. Rodríguez Madrera, R.; Pando Bedriñana, R.; Suárez Valles, B. Production and characterization of aroma compounds from apple pomace by solid-state fermentation with selected yeasts. LWT Food Sci. Technol. 2015, 64, 1342-1353. [CrossRef]

67. Martínez-Avila, O.; Sánchez, A.; Font, X.; Barrena, R. 2-Phenylethanol (Rose Aroma) Production Potential of an Isolated Pichia kudriavzevii Through Solid-State Fermentation. Process. Biochem. 2020, 93, 94-103. [CrossRef]

68. Mantzouridou, F.T.; Paraskevopoulou, A.; Lalou, S. Yeast flavour production by solid state fermentation of orange peel waste. Biochem. Eng. J. 2015, 101, 1-8. [CrossRef]

69. Marella, E.R.; Dahlin, J.; Dam, M.I.; ter Horst, J.; Christensen, H.B.; Sudarsan, S.; Wang, G.; Holkenbrink, C.; Borodina, I. A single-host fermentation process for the production of flavor lactones from non-hydroxylated fatty acids. Metab. Eng. 2019, 61, 427-436. [CrossRef] [PubMed]

70. Ricci, A.; Cirlini, M.; Levante, A.; Dall'Asta, C.; Galaverna, G.; Lazzi, C. Volatile profile of elderberry juice: Effect of lactic acid fermentation using L. plantarum, L. rhamnosus and L. casei strains. Food Res. Int. 2018, 105, 412-422. [CrossRef] [PubMed]

71. Willrodt, C.; Hoschek, A.; Bühler, B.; Schmid, A.; Julsing, M.K. Decoupling production from growth by magnesium sulfate limitation boosts de novo limonene production. Biotechnol. Bioeng. 2015, 113, 1305-1314. [CrossRef]

72. Martínez-Avila, O.; Sánchez, A.; Font, X.; Barrena, R. Fed-Batch and Sequential-Batch Approaches to Enhance the Bioproduction of 2-Phenylethanol and 2-Phenethyl Acetate in Solid-State Fermentation Residue-Based Systems. J. Agric. Food Chem. 2019, 67, 3389-3399. [CrossRef]

73. Xie, H.; Ma, Q.; Wei, D.Z.; Wang, F.Q. Transcriptomic analysis of Aspergillus niger strains reveals the mechanism underlying high citric acid productivity. Bioresour. Bioprocess. 2018, 5, 1-23. [CrossRef]

74. Sharma, A.; Sharma, P.; Singh, J.; Singh, S.; Nain, L. Prospecting the Potential of Agroresidues as Substrate for Microbial Flavor Production. Front. Sustain. Food Syst. 2020, 4, 18. [CrossRef]

75. Try, S.; Voilley, A.; Chunhieng, T.; De-Coninck, J.; Waché, Y. Aroma compounds production by solid state fermentation, importance of in situ gas-phase recovery systems. Appl. Microbiol. Biotechnol. 2018, 102, 7239-7255. [CrossRef]

76. Berger, R.G. Flavours and Fragrances: Chemistry, Bioprocessing and Sustainability; Springer: Berlin/Heidelberg, Germany, 2007; ISBN 9783540493389.

77. Azmir, J.; Zaidul, I.S.M.; Rahman, M.M.; Sharif, K.M.; Mohamed, A.; Sahena, F.; Jahurul, M.H.A.; Ghafoor, K.; Norulaini, N.A.N.; Omar, A.K.M. Techniques for extraction of bioactive compounds from plant materials: A review. J. Food Eng. 2013, 117, 426-436. [CrossRef]

78. Mazzoli, R.; Bosco, F.; Mizrahi, I.; Bayer, E.A.; Pessione, E. Towards lactic acid bacteria-based biorefineries. Biotechnol. Adv. 2014, 32, 1216-1236. [CrossRef]

79. Spaggiari, M.; Ricci, A.; Calani, L.; Bresciani, L.; Neviani, E.; Dall'Asta, C.; Lazzi, C.; Galaverna, G. Solid state lactic acid fermentation: A strategy to improve wheat bran functionality. LWT 2020, 118, 108668. [CrossRef]

80. Ricci, A.; Cirlini, M.; Guido, A.; Liberatore, C.M.; Ganino, T.; Lazzi, C.; Chiancone, B. From byproduct to resource: Fermented apple pomace as beer flavoring. Foods 2019, 8, 309. [CrossRef] 
81. Ricci, A.; Marrella, M.; Hadj Saadoun, J.; Bernini, V.; Godani, F.; Dameno, F.; Neviani, E.; Lazzi, C. Development of Lactic Acid-Fermented Tomato Products. Microorganisms 2020, 8, 1192. [CrossRef]

82. Martelli, F.; Cirlini, M.; Lazzi, C.; Neviani, E.; Bernini, V. Solid-State Fermentation of Arthrospira platensis to Implement New Food Products: Evaluation of Stabilization Treatments and Bacterial Growth on the Volatile Fraction. Foods 2021, 10, 67. [CrossRef] [PubMed]

83. Sharmila, V.G.; Kavitha, S.; Obulisamy, P.K.; Banu, J.R. Production of fine chemicals from food wastes. In Food Waste to Valuable Resources; Elsevier: Amsterdam, The Netherlands, 2020; pp. 163-188.

84. Smid, E.J.; Kleerebezem, M. Production of Aroma Compounds in Lactic Fermentations. Annu. Rev. Food Sci. Technol. 2014, 5, 313-326. [CrossRef] [PubMed]

85. García-Quintáns, N.; Repizo, G.; Martín, M.; Magni, C.; López, P. Activation of the diacetyl/acetoin pathway in Lactococcus lactis subsp. lactis bv. diacetylactis CRL264 by acidic growth. Appl. Environ. Microbiol. 2008, 74, 1988-1996. [CrossRef]

86. Papagianni, M. Metabolic engineering of lactic acid bacteria for the production of industrially important compounds. Comput. Struct. Biotechnol. J. 2012, 3, e201210003. [CrossRef]

87. Hugenholtz, J.; Kleerebezem, M.; Starrenburg, M.; Delcour, J.; De Vos, W.; Hols, P. Lactococcus lactis as a Cell Factory for High-Level Diacetyl Production. Appl. Environ. Microbl. 2000, 66, 4112-4114. [CrossRef]

88. Guo, T.; Kong, J.; Zhang, L.; Zhang, C.; Hu, S. Fine Tuning of the Lactate and Diacetyl Production through Promoter Engineering in Lactococcus lactis. PLoS ONE 2012, 7, e36296.

89. Flahaut, N.A.L.; de Vos, W.M. Systems biology and metabolic engineering of lactic acid bacteria for improved fermented foods. In Advances in Fermented Foods and Beverages: Improving Quality, Technologies and Health Benefits; Elsevier Inc.: Amsterdam, The Netherlands, 2015; pp. 177-196. ISBN 9781782420248.

90. Bancalari, E.; Montanari, C.; Levante, A.; Alinovi, M.; Neviani, E.; Gardini, F.; Gatti, M. Lactobacillus paracasei 4341 as adjunct culture to enhance flavor in short ripened Caciotta-type cheese. Food Res. Int. 2020, 135, 109284. [CrossRef]

91. Levante, A.; Bancalari, E.; Tambassi, M.; Lazzi, C.; Neviani, E. Phenotypic Diversity of Lactobacillus casei group isolates as a selection criterion for use as secondary adjunct starters. Microorganisms 2020, 8, 128. [CrossRef]

92. Chen, C.; Lu, Y.; Yu, H.; Chen, Z.; Tian, H. Influence of 4 lactic acid bacteria on the flavor profile of fermented apple juice. Food Biosci. 2019, 27, 30-36. [CrossRef]

93. Di Cagno, R.; Filannino, P.; Gobbetti, M. Lactic acid fermentation drives the optimal volatile flavor-aroma profile of pomegranate juice. Int. J. Food Microbiol. 2017, 248, 56-62. [CrossRef]

94. Nsogning Dongmo, S.; Sacher, B.; Kollmannsberger, H.; Becker, T. Key volatile aroma compounds of lactic acid fermented malt based beverages-Impact of lactic acid bacteria strains. Food Chem. 2017, 229, 565-573. [CrossRef]

95. Szutowska, J. Functional properties of lactic acid bacteria in fermented fruit and vegetable juices: A systematic literature review. Eur. Food Res. Technol. 2020, 246, 357-372. [CrossRef]

96. Ali Abdel-Rahman, M.; Tashiro, Y.; Sonomoto, K. Lactic acid production from lignocellulose-derived sugars using lactic acid bacteria: Overview and limits. J. Biotechnol. 2011, 156, 286-301. [CrossRef] [PubMed]

97. Wang, X.; Wang, G.; Yu, X.; Chen, H.; Sun, Y.; Chen, G. Pretreatment of corn stover by solid acid for D-lactic acid fermentation. Bioresour. Technol. 2017, 239, 490-495. [CrossRef] [PubMed]

98. Tarraran, L.; Mazzoli, R. Alternative strategies for lignocellulose fermentation through lactic acid bacteria: The state of the art and perspectives. FEMS Microbiol. Lett. 2018, 365, 126. [CrossRef]

99. Escamilla-Hurtado, M.L.; Valdés-Martínez, S.E.; Soriano-Santos, J.; Gómez-Pliego, R.; Verde-Calvo, J.R.; Reyes-Dorantes, A.; Tomasini-Campocosio, A. Effect of culture conditions on production of butter flavor compounds by Pediococcus pentosaceus and Lactobacillus acidophilus in semisolid maize-based cultures. Int. J. Food Microbiol. 2005, 105, 305-316. [CrossRef] 